\title{
2015 injury deaths in Canada
}

\section{Xiaoquan Yao, MSc; Robin Skinner, MSP; Steven McFaull, MSc; Wendy Thompson, MSc}

\begin{abstract}
Injuries continue to be a public health concern in Canada. National injury death data are essential for understanding the magnitude and pattern of injuries. This paper used the Vital Statistics - Death database to examine deaths associated with injuries in 2015. Injuries were ranked against causes of death, and more in-depth analysis of injury categories was conducted by sex and age. Unintentional injuries were the $6^{\text {th }}$ leading causes of death overall, with different ranking by sex. Among unintentional injury deaths, leading causes included falls, poisonings, motor vehicle traffic collisions, and suffocation, which varied by age group.
\end{abstract}

Keywords: mortality, leading causes, injuries, unintentional injuries, suicide, falls, poisonings, motor vehicle traffic collisions

\section{Introduction}

An injury is defined as the transfer of energy to human beings at rates and in amounts above or below the tolerance of human tissue. The amount of the energy concentration outside the bands of tolerance of the tissue determines the severity of the injury. ${ }^{1}$ The external causes include falls, motor vehicle traffic collisions, poisonings, suffocation, drowning, fire, struck by/against and others. ${ }^{2}$ Injuries are classified as either unintentional or intentional. Unintentional injuries occur without an intent of harm such as when someone is hurt from a fall or burn or in a traffic collision. ${ }^{2}$ Intentional injuries result from a deliberate act of harm to oneself or another such as suicide or homicide. ${ }^{2}$ When the intent is unclear, the injury is classified as undetermined intent.

Injuries are a public health concern both globally and in Canada. Globally, almost 5 million people die from injuries each year, which accounts for $9 \%$ of the world's deaths. ${ }^{3}$ According to the WHO, road traffic injuries are the leading cause of death among 15-29-year-olds, with suicide and homicide the $2^{\text {nd }}$ and $4^{\text {th }}$ leading causes of death in this population, respectively. ${ }^{3}$

In Canada, injuries claimed 16094 lives and were the leading cause of death among 1-44-year-olds in 2010. ${ }^{4}$ According to the Cost of Injury in Canada Report, injuries were associated with an economic burden of $\$ 26.8$ billion in Canada in 2010, among which $\$ 15.9$ billion were from health care expenditures and $\$ 10.9$ billion were due to reduced productivity from hospitalization, disability and premature death. ${ }^{4}$

Monitoring why and how people die and how diseases and injuries affect people, their families, the health care system and society is important. Ongoing reporting of national injury death data are essential for understanding the trend and burden of injuries at the national level, which is important for targeted injury prevention. This paper provides Canadian statistics on injury deaths for 2015. To highlight the burden of injuries in the context of all causes of death, the paper also provides the leading causes of all deaths, allowing injury categories to be compared to other causes of mortality.

\section{Highlights}

- Ongoing reporting of national injury death data is essential for understanding the trend and burden of injuries at the national level in Canada

- In 2015, unintentional injuries were the $6^{\text {th }}$ leading cause of death overall and the leading cause for those aged 1-34. Suicide ranked as the $2^{\text {nd }}$ leading cause of death for 15-34-year-olds.

- Falls, poisonings and motor vehicle traffic collisions are the top three leading causes among unintentional injury deaths.

\section{Methods}

The data source used was Statistics Canada's Vital Statistics - Death 2015; ${ }^{5}$ the causes of death were coded according to ICD-10 (International Statistical Classification of Diseases and Related Health Problems, Tenth Revision). ${ }^{6}$ The population estimates on July $1^{\text {st }}$, 2015, from Statistics Canada $^{7}$ were used as the denominator for rate calculation.

The causes of all disease and injury deaths were classified and compared according to the ICD-10 classification. More in-depth analysis was conducted on injury deaths by intent (unintentional, suicide, homicide, legal intervention/war, or undetermined intent), as defined in ICD-10. Select external causes of injury (e.g., poisoning, suffocation) were compared with the exclusion of complications of medical and surgical care whose nature and prevention measures are different from most injuries. ${ }^{2}$ 
Pooled and stratified (by sex and age) analyses were undertaken. The SAS Enterprise Guide version $5.1^{8}$ was used to compile the counts and rates.

\section{Results}

In the following text, all rates are per 100000 population and age-standardized rates (ASRs) are based on the 2015 Canadian population with both sexes combined.

\section{Leading causes of all deaths}

Table 1 shows the counts and rates for the leading causes of all deaths. Overall, cancer, circulatory and respiratory system diseases ranked as the top three leading causes for both males and females.

Unintentional injuries were the $6^{\text {th }}$ leading cause of death overall $(\mathrm{n}=11833$; rate $=33.0$ ), and by sex, the $5^{\text {th }}$ for males and $7^{\text {th }}$ for females. The unintentional injury mortality rate for males $(38.8$; $95 \%$ confidence interval [CI]: 37.9-39.7) was significantly higher than females (27.4; 95\% CI: 26.6-28.1). The difference was even larger if the ASRs are examined (43.3; $95 \%$ CI: $42.2-44.3$ vs. 23.6 ; $95 \%$ CI: 23.0-24.3]). Across all age groups, unintentional injuries ranked among the top eight leading causes. They were the leading cause of death for those aged $1-34$, the $2^{\text {nd }}$ leading cause for the ages of $35-44$, and $3^{\text {rd }}$ for children less than 1 year of age and for those aged 45-64.

Suicide ranked as the $11^{\text {th }}$ leading cause of death overall and in females, but the $9^{\text {th }}$ in males. It was also among the leading cause among youth and young adults. Suicide was the $2^{\text {nd }}$ leading cause of death among 15-34-year-olds and the $3^{\text {rd }}$ leading cause of death among 10-14- and 35-44-year-olds. Among the older population (45-64 years), suicide was the $6^{\text {th }}$ leading cause of death.

Homicide ranked among the top 10 leading causes of death among young Canadians less than 35 years old. It was the $4^{\text {th }}, 5^{\text {th }}$ and $6^{\text {th }}$ leading cause of death among those aged 20-24, 15-19 and 25-34 years respectively.

\section{Leading causes of injury deaths}

Table 2 displays the counts and rates of deaths associated with injuries by intent and with additional detail on leading causes of unintentional injuries.

In 2015, there were 17371 deaths (rate $=48.5$ ) associated with injuries, 10957 males and 6414 females. Unintentional injuries accounted for $68.1 \%$ of total deaths associated with injuries, followed by suicide at $25.4 \%$. Leading causes of death among unintentional injuries included falls $(39.8 \%)$, poisonings (19.9\%), motor vehicle traffic collisions (MVT) (15.8\%), followed by suffocation, drowning, fire/flame and struck by/against.

Males had a higher overall injury mortality rate $(61.7 ; 95 \%$ CI: 60.5-62.8) than females (35.5; $95 \%$ CI: 34.6-36.4). Higher unintentional injury mortality rates were observed in males compared to females for all leading causes except for falls. However, the ASRs associated with falls also showed that males $(15.7 ; 95 \% \mathrm{CI}$ : 15.0-16.4) exceed females (11.3; $95 \%$ CI: 10.8-11.7). Males and females shared similar ranking of leading causes of unintentional deaths, except for drowning and fire/flame; however, when the ranking was examined by age groups, there was greater variation. Suffocation, MVT and poisonings were the leading cause of death, respectively, for those aged less than 1 year, 1-24 years and 25-64 years. For those 65 and over, falls accounted for $64.6 \%$ of deaths due to unintentional injury. Suicide resulted in more deaths than any cause of unintentional injuries for those aged 10-64.

\section{Discussion}

Injuries can greatly impact individuals, families and societies. This paper provides national injury death statistics by sex and age group that is critical in understanding the magnitude and pattern of injuries for effective prevention initiatives.

In 2015, unintentional injuries are one of the top 10 leading causes of death in Canada, among males and females, and across all age groups (Table 1). Males have a significantly higher mortality rate for unintentional injury compared to females. The difference in ASRs was even larger. Males displayed higher mortality rates than females in all leading causes except falls. However, the ASRs associated with falls also showed that males exceed females. This is primarily due to the facts that there are more females than males in Canada over the age of 60 and that the mortality rate associated with falls increases sharply in the older population. Detailed examination showed that males had higher mortality rates associated with falls compared to females almost across all 5-year age groups. When age differences are examined, the older age categories had much higher mortality rates from unintentional injuries than younger groups, but lower rank than younger groups due to the increase of chronic diseases. This indicates the prevention strategies should differ in various age populations.

Of note is the rise in poisonings to the $2^{\text {nd }}$ leading cause of unintentional injury deaths overall (Table 2). Prior to 2014, MVT was consistently in this position. Further investigation is necessary to understand the role of unintentional poisonings from opioids and other illicit drugs in this increase. ${ }^{9}$

Suicide ranked as the $2^{\text {nd }}$ leading cause of overall death for 15-34-year-olds behind unintentional injuries for 2015 (Table 1); however, when the external causes among unintentional injuries were examined, suicides surpassed unintentional MVT deaths in those aged 15-34 years. This highlights the need for effective suicide prevention in this population.

\section{Limitations}

The Canadian Vital Statistics - Death database only reports the underlying cause of death that initiates the train of events leading directly to death ${ }^{10}$ and does not include other injuries which may have played a role in death, leading to potential underreporting of injury-related mortality.

This paper is only intended to provide high-level information important for stakeholders to evaluate the burden of injury in comparison to other causes of death to inform injury prevention programs. The data will be updated when newer mortality data become available.

\section{Conclusion}

Injuries remain among the leading causes of death for 2015 in Canada. Overall, men have a higher risk of death from unintentional injuries than women; however, the leading causes of death from unintentional injuries vary for Canadians across the lifespan. Unintentional injuries, suicide, and homicide are responsible for many deaths of young Canadians. This paper provides 


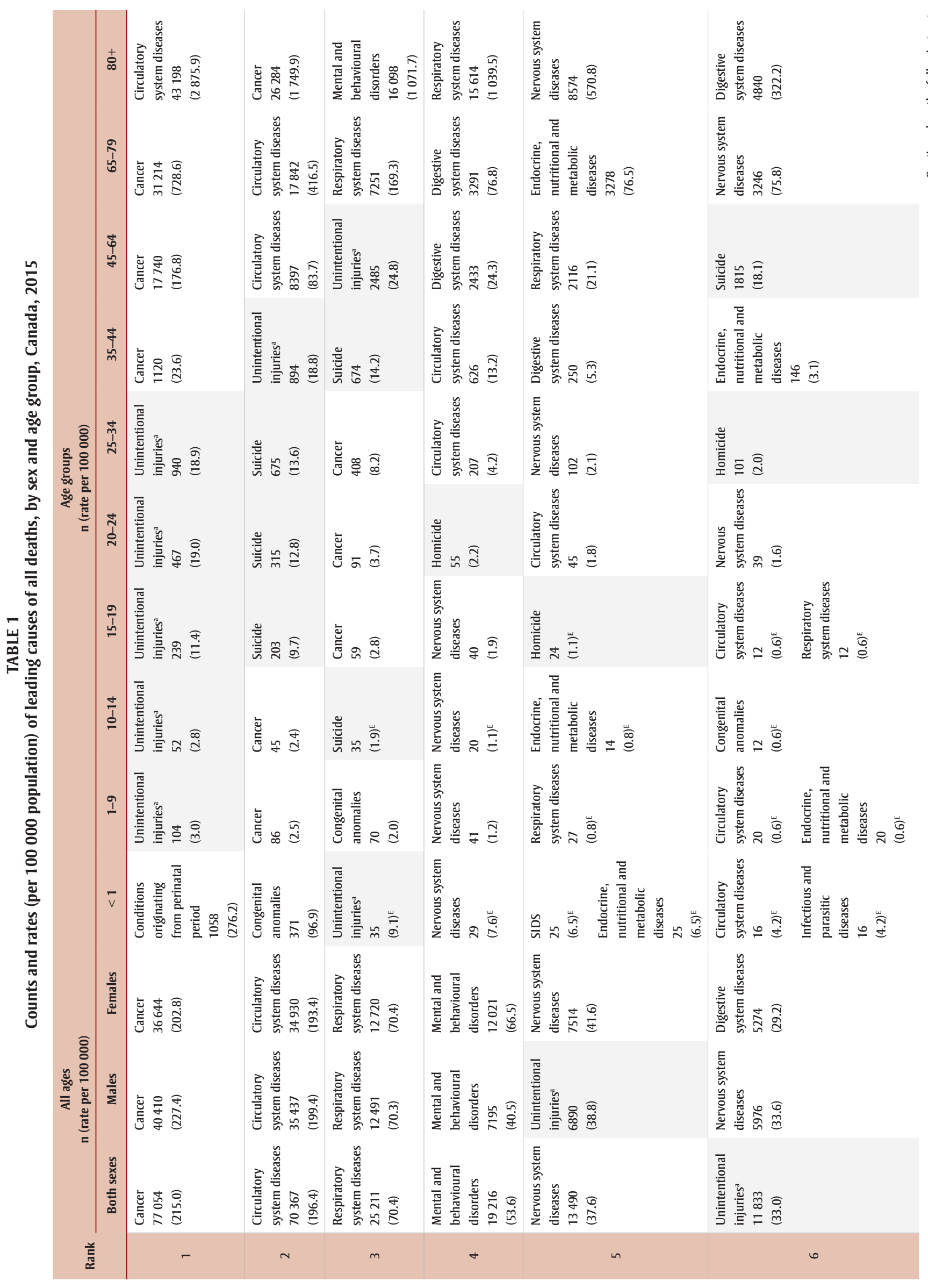




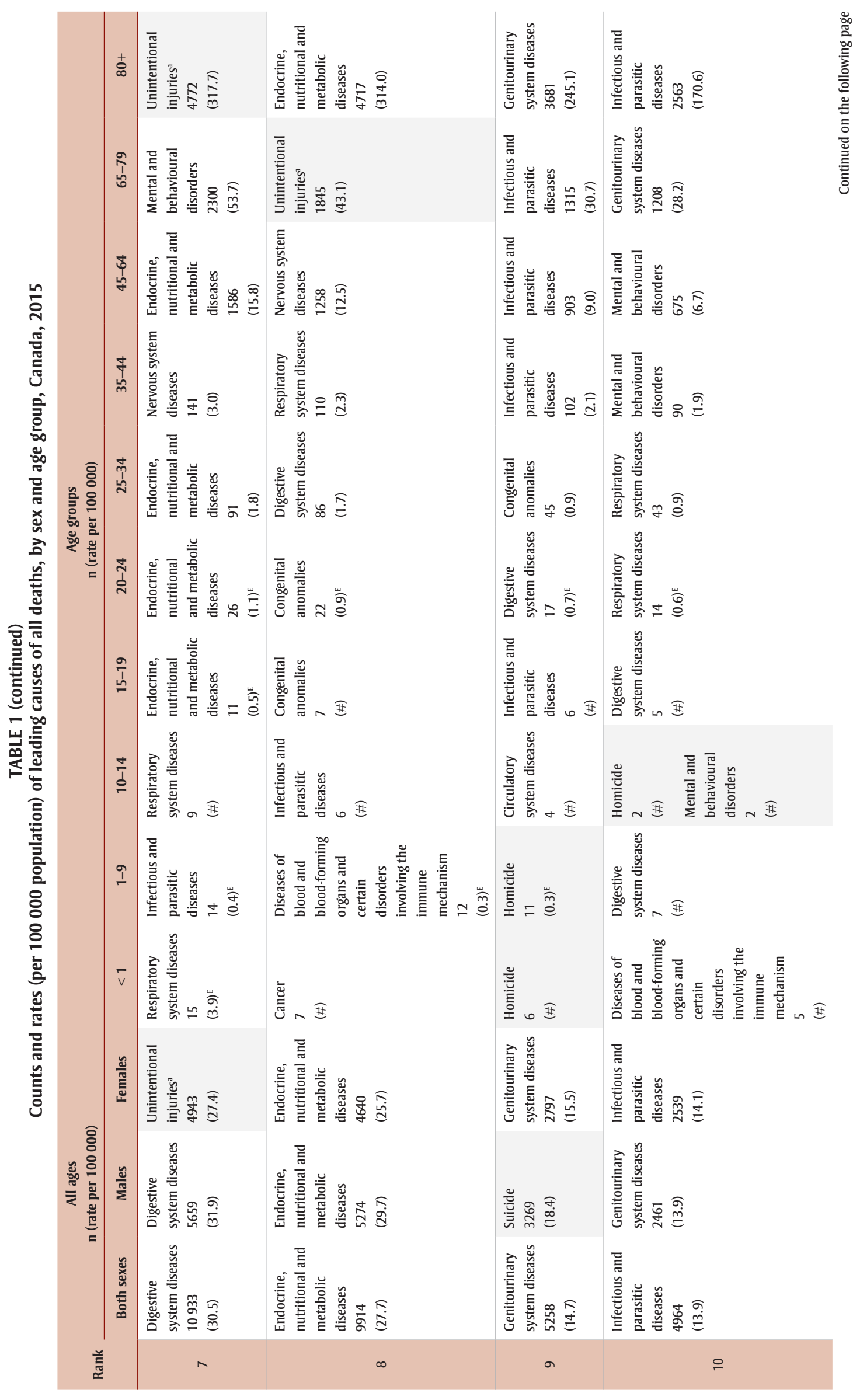




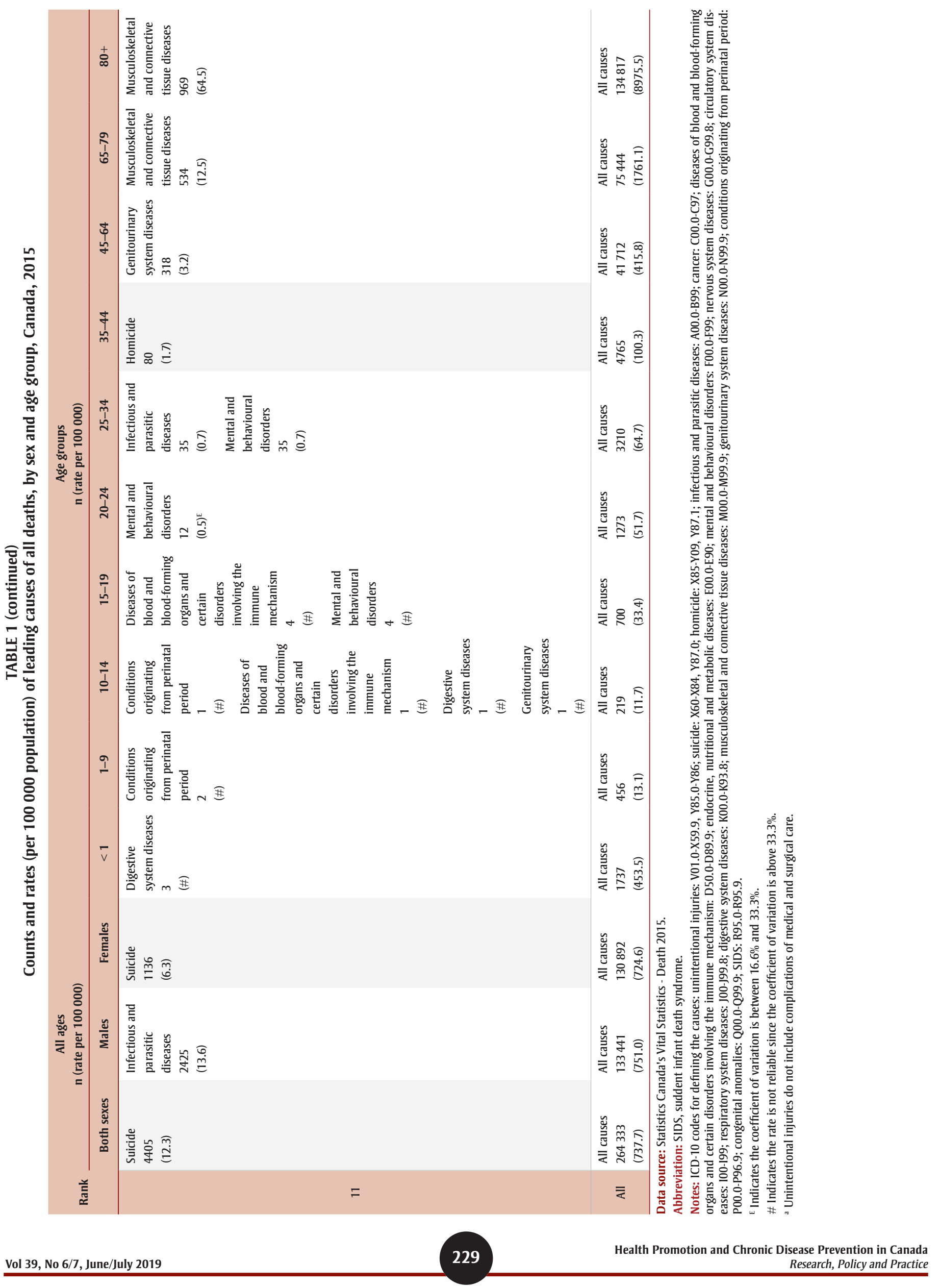


TABLE 2

Counts and rates (per 100000 population) of leading causes of injury deaths, by sex and age group, Canada, 2015

\begin{tabular}{|c|c|c|c|c|c|c|c|c|c|c|c|c|c|}
\hline & \multicolumn{3}{|c|}{$\begin{array}{c}\text { All ages } \\
\text { n (rate per } 100000)\end{array}$} & \multicolumn{10}{|c|}{$\begin{array}{c}\text { Age groups } \\
\text { n (rate per } 100000)\end{array}$} \\
\hline & $\begin{array}{l}\text { Both } \\
\text { sexes }\end{array}$ & Males & Females & $<1$ & $1-9$ & $10-14$ & $15-19$ & $20-24$ & $25-34$ & $35-44$ & $45-64$ & $65-79$ & $80+$ \\
\hline $\begin{array}{l}\text { All injuries } \\
\text { (excluding complications of } \\
\text { medical and surgical care) }\end{array}$ & $\begin{array}{c}17371 \\
(48.5)\end{array}$ & $\begin{array}{l}10957 \\
(61.7)\end{array}$ & $\begin{array}{r}6414 \\
(35.5)\end{array}$ & $\begin{array}{c}45 \\
(11.7)\end{array}$ & $\begin{array}{l}120 \\
(3.4)\end{array}$ & $\begin{array}{c}91 \\
(4.9)\end{array}$ & $\begin{array}{c}486 \\
(23.2)\end{array}$ & $\begin{array}{c}886 \\
(36.0)\end{array}$ & $\begin{array}{c}1880 \\
(37.9)\end{array}$ & $\begin{array}{c}1781 \\
(37.5)\end{array}$ & $\begin{array}{r}4680 \\
(46.6)\end{array}$ & $\begin{array}{l}2417 \\
(56.4)\end{array}$ & $\begin{array}{c}4985 \\
(331.9)\end{array}$ \\
\hline $\begin{array}{l}\text { Unintentional injuries } \\
\text { (excluding complications of } \\
\text { medical and surgical care) }^{\mathrm{a}}\end{array}$ & $\begin{array}{l}11833 \\
(33.0)\end{array}$ & $\begin{array}{r}6890 \\
(38.8)\end{array}$ & $\begin{array}{l}4943 \\
(27.4)\end{array}$ & $\begin{array}{c}35 \\
(9.1)^{\mathrm{E}}\end{array}$ & $\begin{array}{l}104 \\
(3.0)\end{array}$ & $\begin{array}{c}52 \\
(2.8)\end{array}$ & $\begin{array}{c}239 \\
(11.4)\end{array}$ & $\begin{array}{c}467 \\
(19.0)\end{array}$ & $\begin{array}{c}940 \\
(18.9)\end{array}$ & $\begin{array}{c}894 \\
(18.8)\end{array}$ & $\begin{array}{l}2485 \\
(24.8)\end{array}$ & $\begin{array}{l}1845 \\
(43.1)\end{array}$ & $\begin{array}{c}4772 \\
(317.7)\end{array}$ \\
\hline Falls & $\begin{array}{l}4711 \\
(13.1)\end{array}$ & $\begin{array}{l}2187 \\
(12.3)\end{array}$ & $\begin{array}{l}2524 \\
(14.0)\end{array}$ & $\begin{array}{c}0 \\
(0)\end{array}$ & $\begin{array}{c}4 \\
(\#)\end{array}$ & $\begin{array}{c}2 \\
(\#)\end{array}$ & $\begin{array}{c}8 \\
(\#)\end{array}$ & $\begin{array}{c}13 \\
(0.5)^{\mathrm{E}}\end{array}$ & $\begin{array}{c}24 \\
(0.5)^{\mathrm{E}}\end{array}$ & $\begin{array}{c}48 \\
(1.0)\end{array}$ & $\begin{array}{l}338 \\
(3.4)\end{array}$ & $\begin{array}{c}883 \\
(20.6)\end{array}$ & $\begin{array}{c}3391 \\
(225.8)\end{array}$ \\
\hline Poisonings & $\begin{array}{l}2355 \\
(6.6)\end{array}$ & $\begin{array}{l}1647 \\
(9.3)\end{array}$ & $\begin{array}{l}708 \\
(3.9)\end{array}$ & $\begin{array}{c}2 \\
(\#)\end{array}$ & $\begin{array}{c}4 \\
(\#)\end{array}$ & $\begin{array}{c}2 \\
(\#)\end{array}$ & $\begin{array}{c}44 \\
(2.1)\end{array}$ & $\begin{array}{l}164 \\
(6.7)\end{array}$ & $\begin{array}{l}479 \\
(9.7)\end{array}$ & $\begin{array}{c}496 \\
(10.4)\end{array}$ & $\begin{array}{c}997 \\
(10.0)\end{array}$ & $\begin{array}{l}125 \\
(2.9)\end{array}$ & $\begin{array}{c}42 \\
(2.8)\end{array}$ \\
\hline $\begin{array}{l}\text { Motor vehicle traffic } \\
\text { crashes }\end{array}$ & $\begin{array}{l}1871 \\
(5.2)\end{array}$ & $\begin{array}{l}1331 \\
(7.5)\end{array}$ & $\begin{array}{l}540 \\
(3.0)\end{array}$ & $\begin{array}{c}6 \\
(\#)\end{array}$ & $\begin{array}{c}32 \\
(0.9)^{\mathrm{E}}\end{array}$ & $\begin{array}{c}15 \\
(0.8)^{\mathrm{E}}\end{array}$ & $\begin{array}{l}141 \\
(6.7)\end{array}$ & $\begin{array}{l}203 \\
(8.3)\end{array}$ & $\begin{array}{l}284 \\
(5.7)\end{array}$ & $\begin{array}{l}201 \\
(4.2)\end{array}$ & $\begin{array}{l}533 \\
(5.3)\end{array}$ & $\begin{array}{l}274 \\
(6.4)\end{array}$ & $\begin{array}{c}182 \\
(12.1)\end{array}$ \\
\hline Suffocation & $\begin{array}{l}432 \\
(1.2)\end{array}$ & $\begin{array}{l}253 \\
(1.4)\end{array}$ & $\begin{array}{r}179 \\
(1.0)\end{array}$ & $\begin{array}{c}23 \\
(6.0)^{\mathrm{E}}\end{array}$ & $\begin{array}{c}9 \\
(\#)\end{array}$ & $\begin{array}{c}7 \\
(\#)\end{array}$ & $\begin{array}{c}4 \\
(\#)\end{array}$ & $\begin{array}{c}5 \\
(\#)\end{array}$ & $\begin{array}{c}16 \\
(0.3)^{\mathrm{E}}\end{array}$ & $\begin{array}{c}10 \\
(0.2)^{\mathrm{E}}\end{array}$ & $\begin{array}{c}91 \\
(0.9)\end{array}$ & $\begin{array}{l}104 \\
(2.4)\end{array}$ & $\begin{array}{c}163 \\
(10.9)\end{array}$ \\
\hline Drowning & $\begin{array}{l}272 \\
(0.8)\end{array}$ & $\begin{array}{l}200 \\
(1.1)\end{array}$ & $\begin{array}{c}72 \\
(0.4)\end{array}$ & $\begin{array}{c}0 \\
(0)\end{array}$ & $\begin{array}{c}19 \\
(0.5)^{\mathrm{E}}\end{array}$ & $\begin{array}{c}8 \\
(\#)\end{array}$ & $\begin{array}{c}12 \\
(0.6)^{\mathrm{E}}\end{array}$ & $\begin{array}{c}25 \\
(1.0)^{\mathrm{E}}\end{array}$ & $\begin{array}{c}34 \\
(0.7)^{\mathrm{E}}\end{array}$ & $\begin{array}{c}25 \\
(0.5)^{\mathrm{E}}\end{array}$ & $\begin{array}{c}91 \\
(0.9)\end{array}$ & $\begin{array}{c}42 \\
(1.0)\end{array}$ & $\begin{array}{c}16 \\
(1.1)^{\mathrm{E}}\end{array}$ \\
\hline Fire / Flame & $\begin{array}{l}203 \\
(0.6)\end{array}$ & $\begin{array}{c}121 \\
(0.7)\end{array}$ & $\begin{array}{c}82 \\
(0.5)\end{array}$ & $\begin{array}{c}2 \\
(\#)\end{array}$ & $\begin{array}{c}14 \\
(0.4)^{\mathrm{E}}\end{array}$ & $\begin{array}{c}8 \\
(\#)\end{array}$ & $\begin{array}{c}7 \\
(\#)\end{array}$ & $\begin{array}{c}5 \\
(\#)\end{array}$ & $\begin{array}{c}15 \\
(0.3)^{\mathrm{E}}\end{array}$ & $\begin{array}{c}14 \\
(0.3)^{\mathrm{E}}\end{array}$ & $\begin{array}{c}54 \\
(0.5)\end{array}$ & $\begin{array}{c}57 \\
(1.3)\end{array}$ & $\begin{array}{c}27 \\
(1.8)^{\mathrm{E}}\end{array}$ \\
\hline Struck by/against & $\begin{array}{c}89 \\
(0.2)\end{array}$ & $\begin{array}{c}76 \\
(0.4)\end{array}$ & $\begin{array}{c}13 \\
(0.1)^{\mathrm{E}}\end{array}$ & $\begin{array}{c}1 \\
(\#)\end{array}$ & $\begin{array}{c}5 \\
(\#)\end{array}$ & $\begin{array}{c}0 \\
(0)\end{array}$ & $\begin{array}{c}1 \\
(\#)\end{array}$ & $\begin{array}{c}5 \\
(\#)\end{array}$ & $\begin{array}{c}4 \\
(\#)\end{array}$ & $\begin{array}{c}11 \\
(0.2)^{\mathrm{E}}\end{array}$ & $\begin{array}{c}36 \\
(0.4)\end{array}$ & $\begin{array}{c}16 \\
(0.4)^{\mathrm{E}}\end{array}$ & $\begin{array}{c}10 \\
(0.7)^{\mathrm{E}}\end{array}$ \\
\hline $\begin{array}{l}\text { Other unintentional } \\
\text { injuries }\end{array}$ & $\begin{array}{l}1900 \\
(5.3)\end{array}$ & $\begin{array}{l}1075 \\
(6.1)\end{array}$ & $\begin{array}{l}825 \\
(4.6)\end{array}$ & $\begin{array}{c}1 \\
(\#)\end{array}$ & $\begin{array}{c}17 \\
(0.5)^{\mathrm{E}}\end{array}$ & $\begin{array}{c}10 \\
(0.5)^{\mathrm{E}}\end{array}$ & $\begin{array}{c}22 \\
(1.0)^{\mathrm{E}}\end{array}$ & $\begin{array}{c}47 \\
(1.9)\end{array}$ & $\begin{array}{c}84 \\
(1.7)\end{array}$ & $\begin{array}{c}89 \\
(1.9)\end{array}$ & $\begin{array}{l}345 \\
(3.4)\end{array}$ & $\begin{array}{l}344 \\
(8.0)\end{array}$ & $\begin{array}{c}941 \\
(62.6)\end{array}$ \\
\hline Suicide & $\begin{array}{l}4405 \\
(12.3)\end{array}$ & $\begin{array}{l}3269 \\
(18.4)\end{array}$ & $\begin{array}{l}1136 \\
(6.3)\end{array}$ & $\begin{array}{c}0 \\
(0)\end{array}$ & $\begin{array}{c}0 \\
(0)\end{array}$ & $\begin{array}{c}35 \\
(1.9)^{\mathrm{E}}\end{array}$ & $\begin{array}{l}203 \\
(9.7)\end{array}$ & $\begin{array}{c}315 \\
(12.8)\end{array}$ & $\begin{array}{c}675 \\
(13.6)\end{array}$ & $\begin{array}{c}674 \\
(14.2)\end{array}$ & $\begin{array}{l}1815 \\
(18.1)\end{array}$ & $\begin{array}{c}506 \\
(11.8)\end{array}$ & $\begin{array}{c}182 \\
(12.1)\end{array}$ \\
\hline Homicide & $\begin{array}{l}456 \\
(1.3)\end{array}$ & $\begin{array}{l}322 \\
(1.8)\end{array}$ & $\begin{array}{l}134 \\
(0.7)\end{array}$ & $\begin{array}{c}6 \\
(\#)\end{array}$ & $\begin{array}{c}11 \\
(0.3)^{\mathrm{E}}\end{array}$ & $\begin{array}{c}2 \\
(\#)\end{array}$ & $\begin{array}{c}24 \\
(1.1)^{\mathrm{E}}\end{array}$ & $\begin{array}{c}55 \\
(2.2)\end{array}$ & $\begin{array}{l}101 \\
(2.0)\end{array}$ & $\begin{array}{c}80 \\
(1.7)\end{array}$ & $\begin{array}{c}132 \\
(1.3)\end{array}$ & $\begin{array}{c}30 \\
(0.7)^{\mathrm{E}}\end{array}$ & $\begin{array}{c}15 \\
(1.0)^{\mathrm{E}}\end{array}$ \\
\hline Undetermined intent & $\begin{array}{l}664 \\
(1.9)\end{array}$ & $\begin{array}{l}463 \\
(2.6)\end{array}$ & $\begin{array}{c}201 \\
(1.1)\end{array}$ & $\begin{array}{c}4 \\
(\#)\end{array}$ & $\begin{array}{c}5 \\
(\#)\end{array}$ & $\begin{array}{c}2 \\
(\#)\end{array}$ & $\begin{array}{c}19 \\
(1.0)^{\mathrm{E}}\end{array}$ & $\begin{array}{c}45 \\
(1.8)\end{array}$ & $\begin{array}{c}162 \\
(3.3)\end{array}$ & $\begin{array}{l}132 \\
(2.8)\end{array}$ & $\begin{array}{l}243 \\
(2.4)\end{array}$ & $\begin{array}{c}36 \\
(0.8)^{\mathrm{E}}\end{array}$ & $\begin{array}{c}16 \\
(1.1)^{\mathrm{E}}\end{array}$ \\
\hline Legal intervention / war & $\begin{array}{c}13 \\
(0.0)^{\mathrm{E}}\end{array}$ & $\begin{array}{c}13 \\
(0.1)^{\mathrm{E}}\end{array}$ & $\begin{array}{c}0 \\
(0)\end{array}$ & $\begin{array}{c}0 \\
(0)\end{array}$ & $\begin{array}{c}0 \\
(0)\end{array}$ & $\begin{array}{c}0 \\
(0)\end{array}$ & $\begin{array}{c}1 \\
(\#)\end{array}$ & $\begin{array}{c}4 \\
(\#)\end{array}$ & $\begin{array}{c}2 \\
(\#)\end{array}$ & $\begin{array}{c}1 \\
(\#)\end{array}$ & $\begin{array}{c}5 \\
(\#)\end{array}$ & $\begin{array}{c}0 \\
(0)\end{array}$ & $\begin{array}{c}0 \\
(0)\end{array}$ \\
\hline
\end{tabular}

Data source: Statistics Canada's Vital Statistics - Death 2015.

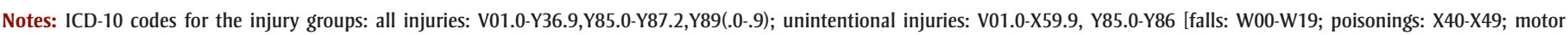
vehicle traffic crashes: V02-V04 (.1), V02-V04 (.9), V09.2,V12-V14 (.3-.9),V19 (.4-.6),V20-V28 (.3-.9),V29 (.4-.9),V30-V79 (.4-.9),V80 (.3-.5),V81-V82(.1),V83-V86(.0-.3),V87 (.0-.8), V89.2; suffoca-

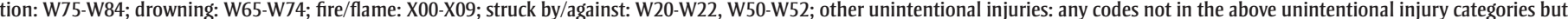
within V01.0-X59.9, Y85.0-Y86]; suicide: X60-X84, Y87.0; homicide: X85-Y09, Y87.1; undetermined intent: Y10-Y34, Y87.2, Y89.9; legal intervention/war: Y35.0-Y36.9,Y89(.0-.1).

${ }^{\mathrm{E}}$ Indicates the coefficient of variation for rate is between $16.6 \%$ and $33.3 \%$.

\# Indicates the rate is not reliable since the coefficient of variation is above $33.3 \%$.

a ICD-10 codes for complications of medical and surgical care: Y40-Y84, Y88. 
useful information to evaluate the burden of injuries and understand the pattern.

\section{Conflicts of interest}

All authors declare no conflicts of interest.

\section{Authors' contributions and statement}

All authors have read and approved of the content of this article. XY was involved in conceptualization, data analysis, interpretation and manuscript preparation. RS, SM and WT were involved in conceptualization, data interpretation and manuscript preparation.

The content and views expressed in this article are those of the authors and do not necessarily reflect those of the Government of Canada.

\section{References}

1. Robertson LS. Injury epidemiology: research and control strategies. Third edition. New York (NY): Oxford University Press; 2007.

2. Public Health Agency of Canada. Injury in Review, 2012 Edition: Spotlight on Road and Transport Safety. Ottawa (ON): Public Health Agency of Canada; 2012.

3. World Health Organization (WHO). Injury and Violence: The Facts 2014 [Internet]. Geneva (Switzerland): WHO; 2014 [cited 3 Dec 2018]. Available from: http://www.who.int/violence_ injury_prevention/media/news/2015 /Injury_violence_facts_2014/en/

4. Parachute. The Cost of Injury in Canada Report [Internet]. Toronto (ON): Parachute; 2015 [cited 3 Dec 2018]. Available from: http://www .parachutecanada.org/costofinjury

5. Statistics Canada. Vital Statistics Death database 2015. Ottawa (ON): Statistics Canada; 2017.

6. World Health Organization (WHO). International Statistical Classification of Diseases and Related Health Problems, Tenth Revision [Internet]. Geneva (Switzerland): WHO; 2016 [cited 3 Dec 2018]. Available from: https://icd.who.int/browse10/2016 /en
7. Statistics Canada. Canadian population estimates by age, sex, and provinces and territories for October 1 , 2017 [internal Statistics Canada dataset]. Ottawa (ON): Statistics Canada; 2017.

8. SAS Institute Inc. SAS Enterprise Guide 5.1. Cary, NC.

9. Health Canada. Opioids and the opioid crisis - Get the facts [Internet]. Ottawa $(\mathrm{ON})$ : Health Canada; [modified 11 Jan 2019; cited 3 Dec 2018]. Available from: https://www.canada.ca/en /health-canada/services/substance-use /problematic-prescription-drug-use /opioids/get-the-facts.html

10. United Nations Statistics Division. Principles and Recommendations for a Vital Statistics System. Revision 3. New York (NY): United Nations; 2014. 